Primljen / Received: 13.12.2011

Ispravljen / Corrected: 9.5.2012.

Prihvaćen / Accepted: 28.8.2012.

Dostupno online / Available online: 15.9.2012.

\section{Fire resistance analysis of steel structures}

Authors:

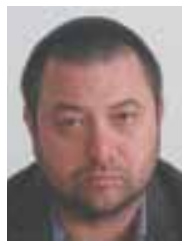

Prof. Ivica Boko, PhD. CE

University of Split

Faculty of Civil Engineering, Arch. and Geodesy ivica.boko@gradst.hr

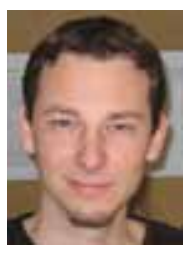

Neno Torić, B.Sc. CE University of Split

Faculty of Civil Engineering, Arch. and Geodesy neno.toric@gradst.hr

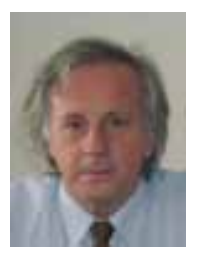

Prof. Bernardin Peroš, PhD. CE

University of Split

Faculty of Civil Engineering, Arch. and Geodesy bernardin.peros@gradst.hr

\section{Ivica Boko, Neno Torić, Bernardin Peroš}

Preliminary note

\section{Fire resistance analysis of steel structures}

Experimental studies conducted to test simple computation models for the determination of resistance of steel structures exposed to fire, as defined in HRN EN 1993-1-2:2008, are presented in the paper. The analysis is made for basic parameters defining reduction of mechanical properties of steel at elevated temperatures, and for basic models for calculating fire resistance of elements subjected to cross-sectional load, and transverse and longitudinal load (bending and bending with longitudinal force).

\section{Key words:}

heat transfer, fire, mechanical properties, steel, longitudinal force bending, bending

\section{Ivica Boko, Neno Torić, Bernardin Peroš}

Prethodno priopćenje

\section{Analiza otpornosti čeličnih konstrukcija u požaru}

U radu je dan prikaz eksperimentalnih istraživanja koja su provedena u svrhu ispitivanja jednostavnih proračunskih modela koji su propisani u normi HRN EN 1993-1-2:2008 za određivanje otpornosti čeličnih konstrukcija izloženih požaru. Analiza je provedena za osnovne parametre smanjenja mehaničkih svojstava čelika na visokim temperaturama te za osnovne modele za proračun požarne otpornosti elemenata izloženih djelovanju poprečnog opterećenja, te poprečnog i uzdužnog opterećenja (savijanje i savijanje s uzdužnom silom).

Ključne riječi:

provodenje topline, požar, mehanička svojstva, čelik, savijanje s uzdužnom silom, savijanje

\section{Ivica Boko, Neno Torić, Bernardin Peroš}

Vorherige Mitteilung

\section{Brandwiderstandsanalyse von Stahlkonstruktionen}

In der Arbeit ist eine Darstellung der experimentellen Forschungen dargestellt, die zum Zwecke der Forschung einfacher Berechnungsmodelle, die nach Norm HRN EN 1993-12:2008 zum Zwecke der Bestimmung der Widerstandsfähigkeit von Stahlkonstruktionen im Falle eines Brandes vorgeschrieben sind aufgezeigt. Die Analyse wurde für grundlegende Parameter der Senkung mechanischer Eigenschaften von Stahl bei hohen Temperaturen sowie für Grundmodelle zur Berechnung des Brandwiderstandes von Elementen, die der Wirkung von Querbelastungen sowie Quer- und Längsbelastung (Biegung und Biegung mit Längskraft) ausgesetzt sind durchgeführt.

\section{Schlüsselwörter:}

Wärmeleitung, Brand, mechanische Eigenschaften, Stahl, Biegung mit Längskraft, Biegung 


\section{Introduction}

The simple calculation methods for calculating the resistance of steel structures exposed to fire have considerably developed especially during the last twenty years due to the modern European norms - structural Eurocodes. The fire resistance of steel elements, within the framework of European norms, is determined by the employment of prescriptive methods or advanced calculation methods for determining the fire resistance of structures. Prescriptive methods are based on a unique representation of fire action in the form of a standard fire curve as well as on the use of the tabulated data for the determination of fire resistance, whereas the advanced methods are based on the determination of fire resistance by employment of complex fire development and heat transfer models in order to determine an objective view of the developed fire temperatures in a steel structure. Furthermore, advanced and prescriptive methods for determining the fire resistance of steel structures are based on the use of simple and advanced calculation models for determining the load bearing capacity of steel structures. Generally, the parameters that determine the level of structure load bearing capacity can be separated into two groups:

- Parameters of degradation of the mechanical properties of a material as a consequence of fire temperatures (yield strength, proportional limit and modulus of elasticity),

- Parameters used as the input data for using simple calculation models of the structure load bearing capacity (parameters that take into account flexural buckling, lateral-torsional buckling and temperature distribution over the cross-section and length of an element).

Given the fact that a variety of different types of steel are being used in civil engineering practice today, there have been certain deviations between the results of the load bearing capacity parameters obtained experimentally and the parameters given by HRN EN1993-1-2:2008. According to the literature, deviations are especially evident in the parameters of the mechanical properties of steel and the stress-strain curves at high temperatures [1].

Tests of simple calculation models of the load bearing capacity of elements exposed to high temperatures given in HRN EN1993-1-2:2008 have been frequently discussed by researchers [2-5], a fact that indicates the complexity of the behaviour of structures in fire even in the case of structures with a simple static system, i.e. when the structure consists of a single span element. The reason for deviations of the experimental results in the prediction of structural fire resistance by using the proposed calculation models is oversimplification of the expected behaviour of steel; it is taken as a material with an idealized elasto-plastic model [6]. Furthermore, the possible deviations of all input parameters which are characteristic of a material built into the elements used for the calculation of the developed temperatures in the element and the calculation of the load bearing capacity can contribute to the deviations of the experimental results as well. Considering the presented facts, it has become necessary to quantify the degree of deviations in the prediction of fire resistance by codified engineering calculation methods with respect to the actual behaviour. It is also important to form new guidelines which would account for the existing deviations and which would be incorporated into the existing norms for the design and calculation of the steel structures exposed to fire.

The objective of this study was to analyze and compare the basic parameters that describe the degradation of the mechanical properties of steel and the simple calculation models of the load bearing capacity for beam elements exposed to fire from four sides according to HRN EN 1993-1$2: 2008$ [7] with the conducted experimental study.

The study [8] includes the determination of the mechanical properties of the batch of steel samples classified as steel grade S355 by the application of steady-state (heating to a previously determined temperature, and subsequently loading the sample with a constant speed of strain increase) and transient heating methods (loading the sample to a predetermined stress level followed by a subsequent heating with a constant temperature increase), as well as the determination of the fire resistance (load bearing capacity) of the elements heated by steady-state or transient heating methods and loaded by vertical forces with and without a longitudinal force.

The paper also presents the methodology used in the presented experimental investigations in order to show the agreement of this study with the tests used to obtain the basic parameters required for describing the behaviour of the structures under fire according to HRN EN 1993-1-2:2008. The analysis of the presented parameters and calculation models for the fire resistance of steel structures was carried out systematically in two stages:

- The comparison of the values of mechanical properties of steel at high temperatures given in HRN EN1993-1-2:2008 with the conducted experimental research for determining the mechanical properties of the batch of steel samples grade $\mathrm{S355}$ at high temperatures,

- The comparison of the results obtained by simple calculation models for the ultimate limit state and for the serviceability limit state of the elements subjected to vertical and longitudinal forces with the respective experimental results.

\section{Previous studies}

This chapter presents experimental and theoretical researches carried out within the study of the mechanical properties and load bearing capacity of steel elements exposed to fire with the emphasis on the researches used for the creation of HRN EN 1993-1-2:2008. 


\subsection{Mechanical properties of steel at high temperatures}

The mechanical properties of steel at high temperatures given in HRN EN 1993-1-2:2008 are determined according to the research carried out by Schleich [9]. His research was based on the study of simply supported beam elements subjected to a vertical concentrated force at midspan and heated by a linear temperature gradient increase of $3,5^{\circ} \mathrm{C} / \mathrm{min}$ in the furnace (transient test). The reduction coefficients for the steel yield strength were determined according to the equality between the ratio of yield strength at high temperatures and yield strength at normal temperatures, and the ratio between the collapse force for a beam element at high temperatures and the collapse force for a beam element at normal temperatures. Short elements were loaded until the final formation of the plastic hinge at midspan, without the possibility of lateral-torsional buckling to occur. Apart from the qualitative determination of the reduction factors for the mechanical properties of steel at high temperatures, the research shows that it is possible to express the load bearing capacity of simply supported beam elements in dependence on the parameter of the reduction of steel yield strength.

\subsection{Stress-strain curves}

For numerical modelling of the structure behaviour under fire, it is necessary to define a set of temperature-dependent stress-strain curves which can be obtained by steady-state and transient heating methods. The stress-strain curves in HRN EN 1993-1-2:2008 were adopted according to the research carried out by Kirby et al [10], as well as by other researchers $[11,12]$. Curves consist of a linear part up to the proportional limit of steel, an elliptic part up to the steel yield strength (stress at $2 \%$ strain) which defines the end of the elastic behaviour of a material. After the elliptic part, curves are defined by the yield plateau (ideal plastic model) in combination with the model for strain hardening which can be used up to a temperature of $400^{\circ} \mathrm{C}$. Kirby et al [13] showed that, at low strain values, the mechanical properties obtained by the transient heating method are conservative unlike the properties obtained by the steady-state heating method.

\subsection{Simple calculation models for fire resistance of steel structures}

Simple calculation models for determining the fire resistance of steel elements are based on the verification of fire resistance in three different domains: time, strength and temperature [14]. The concept of simple calculation models of the fire resistance of elements according to HRN EN 19931-2:2008 is formed by analysing experimental and theoretical investigations [10,15], where the fire resistance calculation was adapted to a codified calculation of the elements' load bearing resistance at room temperature. The research carried out by Kirby et al focused on the unprotected hot-rolled steel I beams and composite beams with different types of support boundary conditions at the end of beams. In the conducted experiment beams and columns were exposed to fire action defined by a standard fire curve at three and four sides of a beam and were loaded by a concrete slab and concentrated forces along the beam length. The experiments showed the dependence of the fire resistance of steel elements on the support boundary conditions, the section factor and the shape of the developed temperature profile in a steel element.

\section{Analysis of the mechanical properties of steel at high temperatures}

This section presents the assessment of the mechanical properties of a batch of carbon steel specimens using the steady-state and transient heating methods [8]. Furthermore, the determination of the stress-strain curves at high temperatures and temperature-strain curves is given, as well as a comparison with HRN EN1993-1-2:2008.

\subsection{Experimental programme}

The mechanical properties of steel at high temperatures were determined experimentally using the steady-state and transient heating methods. The tests were carried out in the laboratory of Steel Structure Division at the Structural department of the Civil Engineering Institute of Croatia (IGH), Zagreb. The tension tests were done using standard steel test specimens with the ratio between the measuring length $\mathrm{L}_{0}$ and the diameter of a specimen $d_{0}$ equalling $10\left(\mathrm{~L}_{0} / \mathrm{d}_{0}=10\right)$. The steady-state and transient heating method were used for heating the specimens in series of two specimens for each temperature level. In the transient heating method, subsequent to pre-stressing, the sample was heated by a heating speed of $10^{\circ} \mathrm{C} / \mathrm{min}$. In the steady-state heating method, after having been heated to a predetermined temperature level, the sample was loaded with a strain increase of 0,02\%/sec.
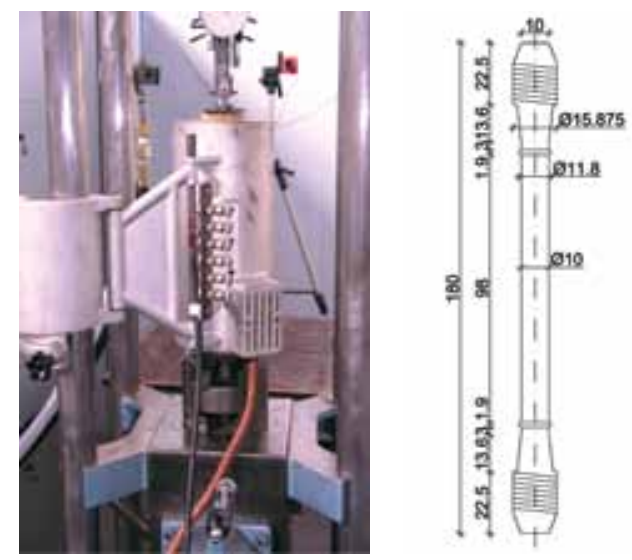

Figure 1. Mobile furnace and a testing specimen 
Figure 1 presents the dimensions of the steel specimen and the mobile furnace in the tensile testing machine used for heating of the specimen. The strain increase in the specimen sample was measured with the help of video-extensometer. This optical device measures the relative distance between two contrast points on the specimen (black/white points) which are located on the special temperature resistant steel markers (non-deformable at high temperatures).

Table 1 presents the chemical composition of the analyzed steel classified as S355J2G3 according to the standard EN10025:1990+A1:1993 provided by the steel manufacturer "Astron", Luxemburg.

Table 1. Chemical composition of the analyzed steel (\%)

\begin{tabular}{|l|c|l|c|}
\hline Chemical element & Portion [\%] & Chemical element & Portion [\%] \\
\hline Carbon, C & 0,163 & Vanadium, V & 0,003 \\
\hline Phosphorus, P & 0,007 & Manganese, Mn & 1,44 \\
\hline Sulphur, S & 0,0012 & Molybdenum, Mo & 0,002 \\
\hline Nitrogen, N & 0,0043 & Niobium, Nb & 0,001 \\
\hline Aluminium, Al & 0,031 & Nickel, Ni & 0,14 \\
\hline Boron, B & 0,0002 & Silicon, Si & 0,220 \\
\hline Chromium, Cr & 0,19 & Titanium, Ti & 0,002 \\
\hline Copper, Cu & 0,19 & & \\
\hline
\end{tabular}

Table 2 presents the results of the mechanical properties of the analyzed steel test specimen at ambient temperature.

Table 2. Mechanical properties of the analyzed steel test specimen at ambient temperature

\begin{tabular}{|c|c|c|c|}
\hline Test specimen & $f y, 20[\mathrm{MPa}]$ & $f u, 20[\mathrm{MPa}]$ & Ey,20 [MPa] \\
\hline $\mathbf{1}$ & 363,3 & 515,3 & 208000,0 \\
\hline $\mathbf{2}$ & 365,4 & 521,3 & 216000,0 \\
\hline $\mathbf{3}$ & 381,2 & 511,2 & 197000,0 \\
\hline $\mathbf{4}$ & 346,8 & 513,5 & 219000,0 \\
\hline $\mathbf{5}$ & 362,6 & 514,4 & 201000,0 \\
\hline $\mathbf{6}$ & 354,9 & 520,8 & 213000,0 \\
\hline Mean [MPa] & 362,4 & 516,1 & 209000,0 \\
\hline St. dev. [MPa] & 11,5 & 4,1 & 8649,0 \\
\hline
\end{tabular}

\subsection{Results - Tests under transient heating conditions}

The results of the assessment of the mechanical properties obtained by the application of the transient heating test method, as well as by the comparison with the experimental data taken from [13] for the same grade of steel and for the heating gradient of $10^{\circ} \mathrm{C} / \mathrm{min}$, are presented in Figure 2.
The comparison from Figure 2 shows that the variations in predictions for the temperature in which the yield strength is reached (stress at $2 \%$ deformation) for the tested steel test specimen, compared with the results obtained by Kirby et al are not significant. Higher discrepancies between the results are observed at the strain level of $1,5 \%$ because of the influence of steel creep strains. The creep strains are dependent on chemical composition of steel, stress level and the total time in which the sample is held under constant load. Consequently, higher discrepancies are also observed at the strain level of $2 \%$, when the specimen is under constant stress $\sim 360 \mathrm{MPa}$, indicating thus the dominant influence of the creep strains on the measured results.

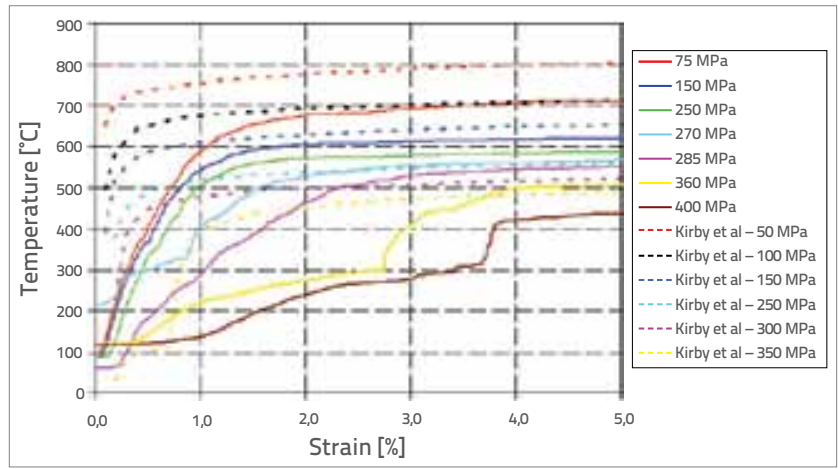

Figure 2. Temperature-strain curves obtained by the transient heating test method and the comparison with the study results [13]

\subsection{Results - Tests under steady-state heating conditions}

Figure 3 presents the stress-strain curves obtained by the steady-state heating test method.

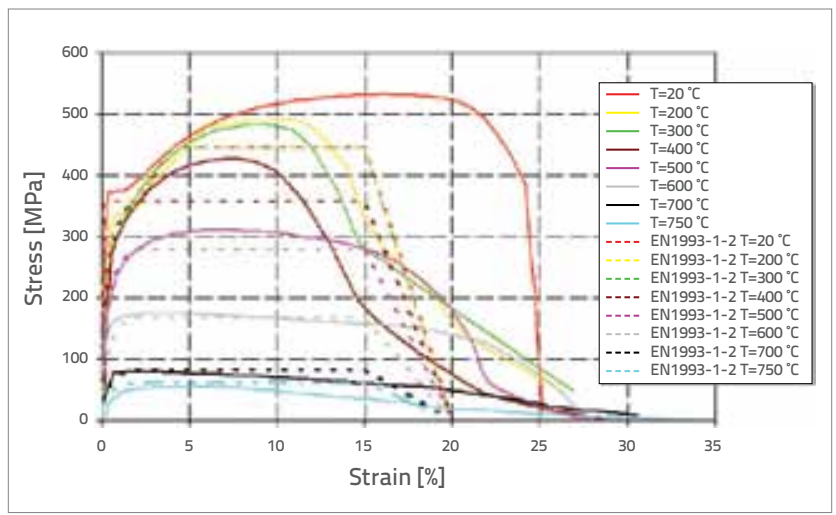

Figure 3. The comparison of the stress-strain curves obtained by the steady-state heating test method with the HRN EN1993-12:2008 model

Figure 3 shows the strain hardening of the tested steel test specimen until a temperature of $400^{\circ} \mathrm{C}$, with good predictions of the phenomenon by HRN EN1993-1-2:2008 curves. The comparison of the length of the yield plateau obtained by the specimen testing with the length of the yield plateau given in HRN EN1993-1-2:2008 shows a satisfactory approximation of 
the Eurocode 3 model. In order to fully perceive the variations of the assessed mechanical properties, Figure 4 presents the variations of the steel yield strength and modulus of elasticity for each type of the test method used for the assessment of the mechanical properties of steel test specimen.

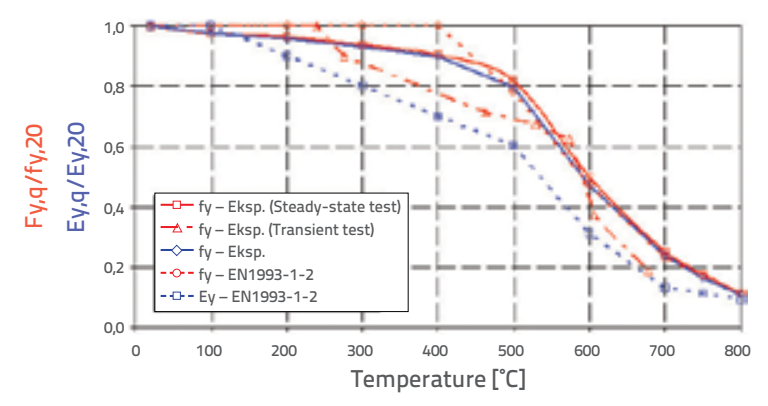

Figure 4. Comparison of the results of the determination of the yield strength ( $2 \%$ deformation) and the tangent modulus of elasticity of steel with the values from HRN EN1993-12:2008

Figure 4 shows small deviations between the value of the yield strength obtained by the experiment and the HRN EN1993-1-2:2008 model in the lower temperature region. $A$ possible reason for the deviation of the results is that the yield strength at high temperatures, according to HRN EN1993-1$2: 2008$, is determined by using a different testing method [9] (testing on elements) in contrast to the presented study in which steel test specimens were tested. The results also show significant deviations of the tangential elastic modulus, with less pronounced deviations of the yield strength compared with the values from HRN EN1993-1-2:2008, especially in the temperature region from $300-600^{\circ} \mathrm{C}$. The values of the yield strength obtained by the transient heating test method (a method that presents a realistic simulation of fire conditions) are generally on the safe side when compared with the values obtained by the steady-state heating test method.

\section{Analysis of simple calculation models for fire resistance}

This section presents the testing programme for steel elements which were heated using the steady-state heating method, and loaded by a vertical force in combination with and without a longitudinal force. Furthermore, the programme for heating the steel elements using the transient heating method is given. In the transient heating test the elements were momentarily loaded by a vertical force and subsequently heated by a nonlinear temperature rise in the furnace until the load bearing capacity was reached. The experiment includes the monitoring of the vertical deflections of elements and the surface temperatures in element points which are presented in the paper [16] (the mentioned paper presents the results of the temperature measurements only for the case of element stationary test of bending and combined bending and axial compression). The element deflections obtained by the tests are compared with the results of the deflections obtained by modelling the elements using the finite element method incorporated in the engineering structural modelling software [17] capable of taking into account the geometrical non-linearity of the structure, but not the non-linearity of the material which includes steel creep at high temperature. In addition, the results of the collapse load of elements obtained by the presented research are compared with the computations of the collapse load obtained by calculating the fire resistance of the steel element subjected to bending and combined bending and longitudinal compression determined according to HRN EN1993-1-2:2008.

\subsection{Experimental programme}

The experimental programme included the heating of steel elements with a span of $2,5 \mathrm{~m}$ by applying the steadystate and transient heating methods (Figure 5), as well as subsequent loading of elements with different types of load (bending and bending combined with longitudinal compression). A lateral support for the element was ensured during the element being loaded at midspan in order to prevent the lateral-torsional buckling. The tests were in entirety carried out in the Laboratory for heat measurements (LTM), Zagreb - Lučko. Tables 3 and 4 present the basic parameters of the experimental programme for testing the behaviour of steel elements at high temperatures.

Table 3. Basic parameters of the experimental programme for testing the behaviour of steel elements at high temperatures - steady-state heating method

\begin{tabular}{|c|c|c|c|c|c|c|c|c|}
\hline \multicolumn{2}{|c|}{ Testing method } & \multicolumn{7}{|c|}{ Steady-state } \\
\hline \multirow{2}{*}{\multicolumn{2}{|c|}{$\begin{array}{c}\text { Load type } \\
\text { Max. temperature }\left[{ }^{\circ} \mathrm{C}\right]\end{array}$}} & \multicolumn{4}{|c|}{ Bending } & \multicolumn{3}{|c|}{ Bending + longitudinal compression } \\
\hline & & 400 & 500 & 600 & 700 & 400 & 500 & 600 \\
\hline \multicolumn{2}{|c|}{ Heating regime } & \multicolumn{4}{|c|}{ Nonlinear } & \multicolumn{3}{|c|}{ Nonlinear } \\
\hline \multirow{2}{*}{ Force $[k N]$} & Longitudinal & \multicolumn{4}{|c|}{-} & \multicolumn{3}{|c|}{400} \\
\hline & Vertical & \multicolumn{4}{|c|}{$150-300$} & \multicolumn{3}{|c|}{$150-400$} \\
\hline
\end{tabular}


Table 4. Basic parameters of the experimental programme for testing the behaviour of steel elements - transient heating method

\begin{tabular}{|c|c|c|}
\hline Testing method & \multicolumn{2}{|c|}{ Transient } \\
\hline Load type & \multicolumn{2}{|c|}{ Bending } \\
\hline Force $[\mathrm{kN}]$ & 200 & 275 \\
\hline Average heating gradient $\left[{ }^{\circ} \mathrm{C} / \mathrm{min}\right]$ & 5 & 10 \\
\hline
\end{tabular}

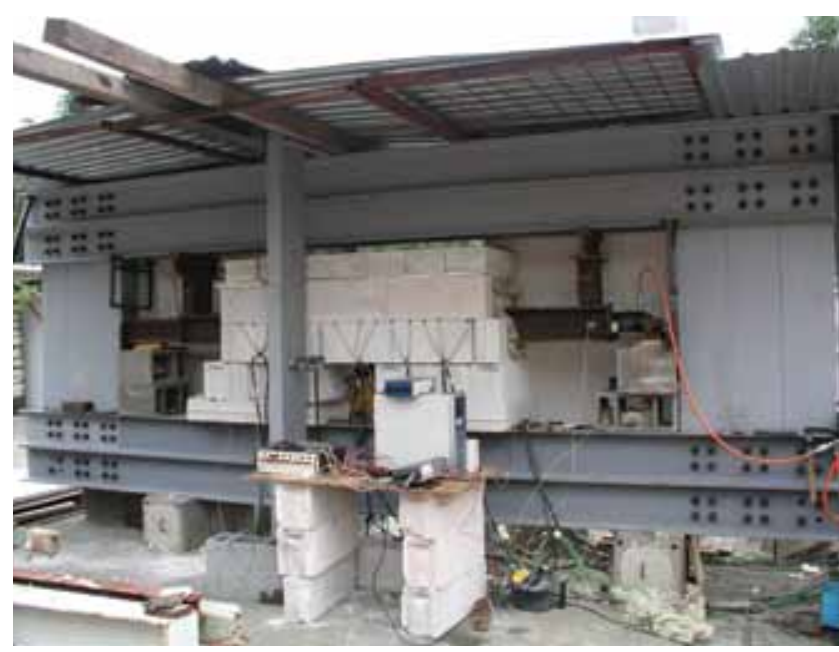

Figure 5. Test setup - furnace with a frame for loading steel elements

\subsection{Modelling of the behaviour of steel elements exposed to fire using the finite element method}

A finite-element-method-based programme package SCIA [17] was used for the prediction of the deflections of the element, loaded as presented in Figure 6. The element was modelled with three finite elements. The central finite element was characterized by a reduced modulus of elasticity depending upon the stress level at the cross-section and the intensity of the predetermined steady-state temperature in the element part within the furnace $\left(400-700^{\circ} \mathrm{C}\right.$ for bending test and $400-600^{\circ} \mathrm{C}$ for the bending test combined with a longitudinal compression). The same type of model was used for predicting the deflection of the element tested by the transient heating method, with the difference being that the deflections at midspan were calculated for discrete values of temperatures developed in the element over the duration of the test.

The computation of the deflection by using a simple calculation model for the case of the steady state heating test was performed in the following manner: the vertical force $V$ in the model was applied incrementally at steps of $20 \mathrm{kN}$ on the basis of which the external load moment was calculated. The external load moment was subsequently used in the calculation of the maximum stress in the extreme fiber of the cross section. Values of the maximum stress in the extreme fiber at the element midspan were used to determine the value of the reduced elastic modulus obtained from the stress-strain curves for the temperature at which the part of the element was heated in the furnace.

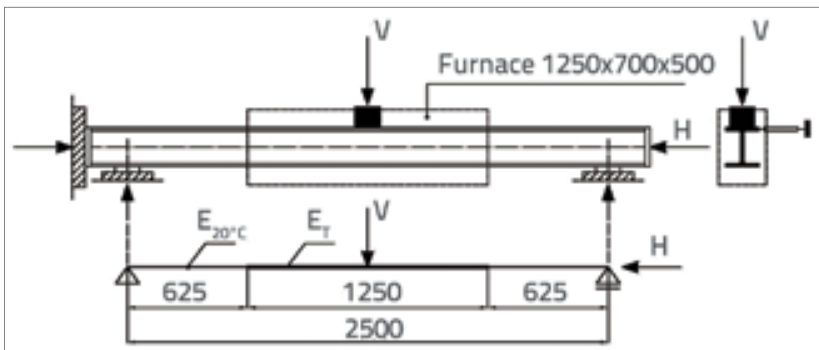

Figure 6. Presentation of the loading type on the element together with a calculation model for the element subjected to bending and combined bending and longitudinal compress

The calculation of the reduced elastic modulus $E_{T}$ was performed for the stress-strain curves taken from HRN EN1993-1-2:2008 and for the curves obtained by the assessment of the mechanical properties of steel using the steady-state heating test method. The two remaining finite elements were characterized by the elastic modulus at atmospheric temperature since the temperature in both parts of the element outside the furnace was slightly increased, which was confirmed by the temperature measurements at surface points outside the furnace [8]. The scheme of the incremental calculation procedure of the deflection at midspan is given in Figure 7.

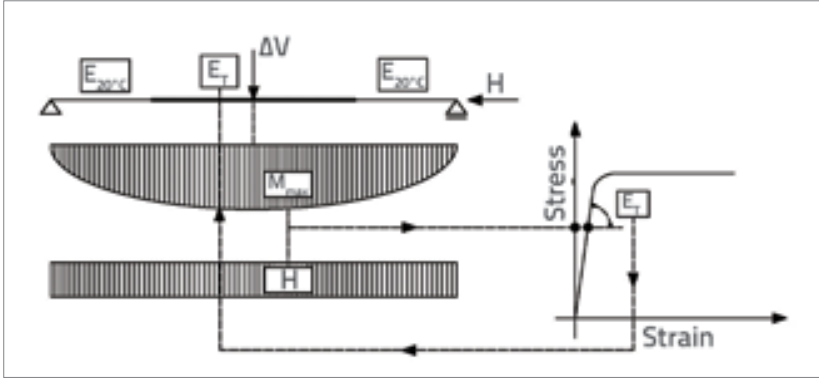

Figure 7. Schematic presentation of the incremental calculation of the deflection at midspan - Models 1 and 2

For the case of the transient heating of the element, the deflection calculation was performed for the temperature increment of $50^{\circ} \mathrm{C}$, since, due to the loading procedure used in the transient heating test, stress level at the element crosssection was constant.

The deflection calculation for the case when the element is additionally loaded with a longitudinal force was performed by using a non-linear static model for the calculation of the inner forces in the element (second order theory calculation), including initial imperfections of the element (initial displacement at midspan equal to $\lambda / 500$, where $\lambda$ is the span of the element). By applying the second order 
theory of calculation of inner forces, additional deflections as a consequence of the longitudinal force at midspan of the element were taken into account.

\subsection{Results of the temperature measurements for the case of transient heating method}

As it was previously noted, in paper [16] detailed temperature measurements in the case of the steady-state test are presented. Consequently, temperature measurements for the case of transient test are presented in the following text.

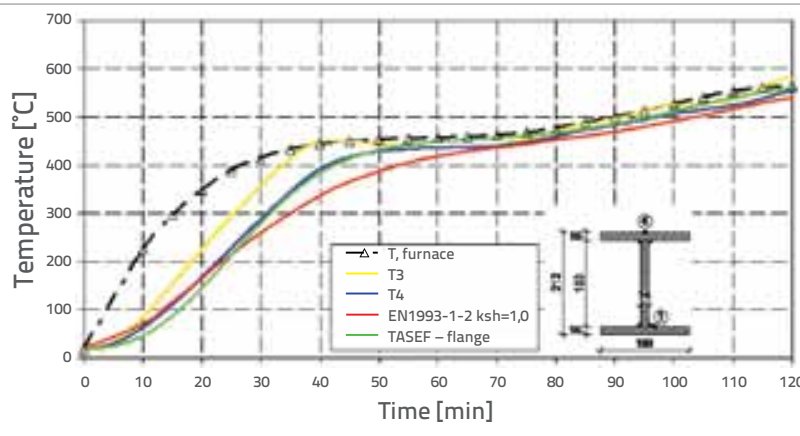

Figure 8. Temperature measurements for the case of transient test $(\mathrm{V}=\mathbf{2 0 0 , 0 \mathrm { kN } )}$

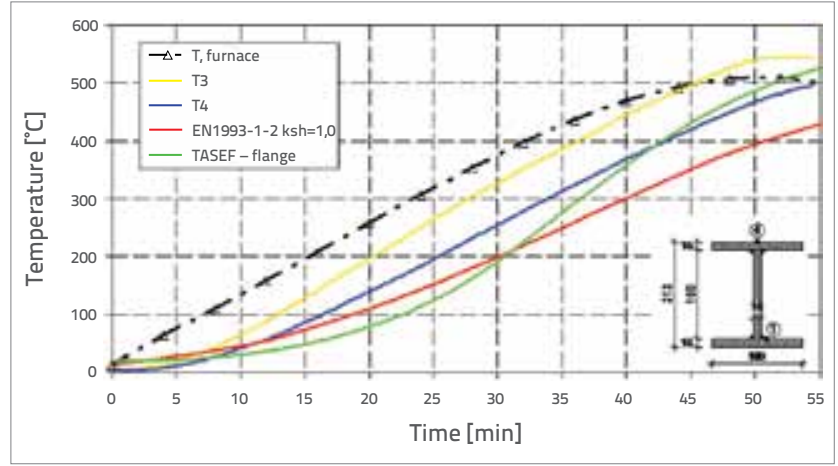

Figure 9. Temperature measurements for the case of transient test ( $\mathrm{V}=\mathbf{2 7 5}, \mathbf{0} \mathrm{kN})$

\subsection{Results of the experiment - bending and combined bending and longitudinal compression}

Figures 10 - 13 present the results of the deflection obtained by experiments for the element subjected to bending, combined bending and longitudinal compression heated using the steady-state and transient heating methods. The results were compared with the deflections obtained by the respective software simulation and are presented as well. For the steady-state heating test, the deflections were calculated by an incremental procedure described in Chapter 4.2 until the stresses in the extreme fiber of the cross-section reached the value of the reduced yield strength $f_{y, \theta}$ depending on the value of the temperature to which the element was heated. As for the transient heating test, the deflections were calculated until the critical temperature was reached at which the reduced elastic modulus $E_{\theta}$ approximately equalled zero. The element deflections at midspan were calculated for the combination of values of the yield strength and the elastic modulus taken from the conducted experiments and from HRN EN1993-1-2:2008.

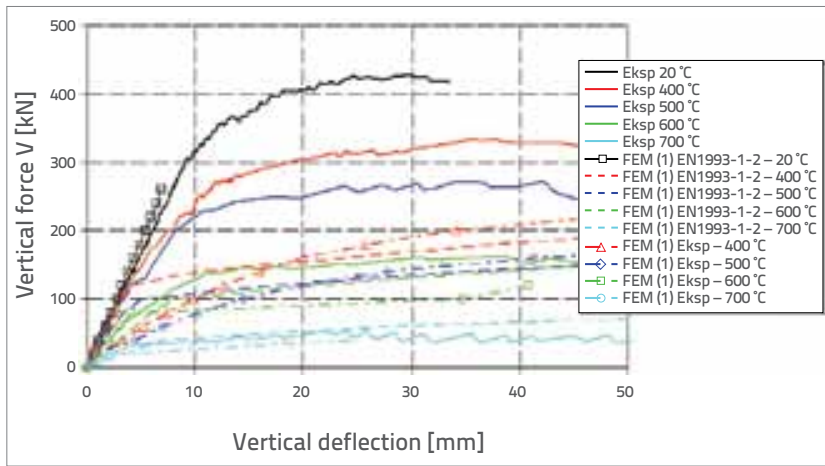

Figure 10. Deflection at midspan for the element subjected to bending (steady-state test)

The prediction of the FEM Model 1 for midspan deflection (the prediction of deflection for the case of bending of the element) agrees with the values of the deflections obtained by experiments only at the temperature of $700^{\circ} \mathrm{C}$, whereas in the predictions of deflection by the FEM Model 2, which models the element subjected to vertical and longitudinal forces, the deviations are present even at that temperature (Figures 10 and 11).

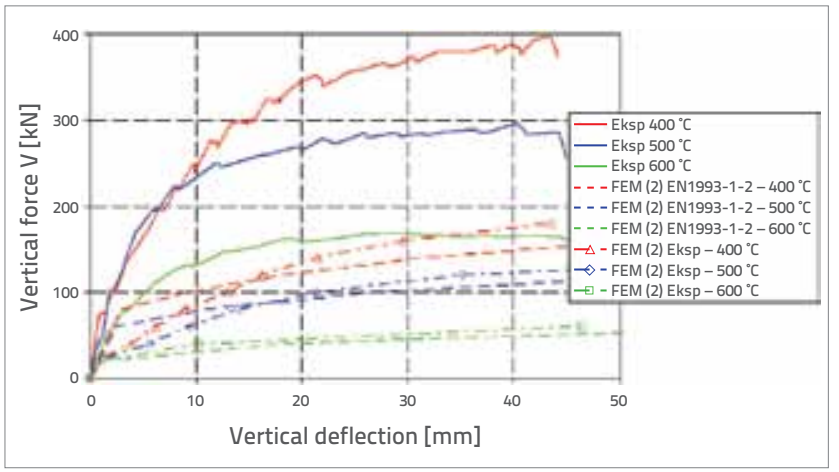

Figure 11. Deflection at midspan for the element subjected to combined bending and longitudinal compression (steadystate test)

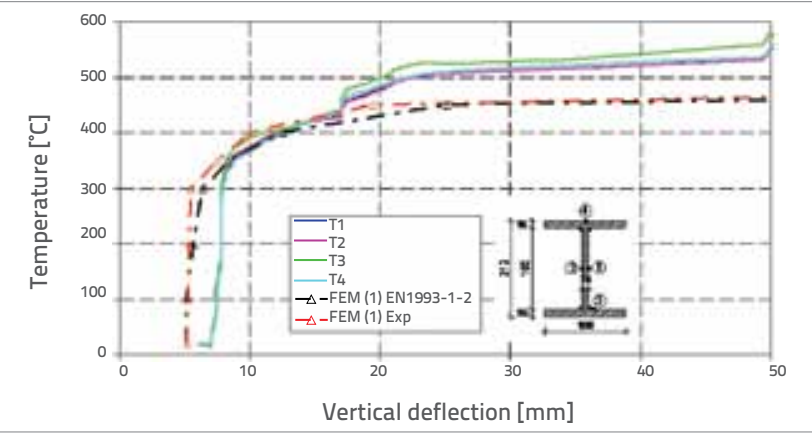

Figure 12. Deflection at midspan for the element subjected to bending (transient test, $\mathrm{V}=\mathbf{2 0 0} \mathrm{kN}$ ) 


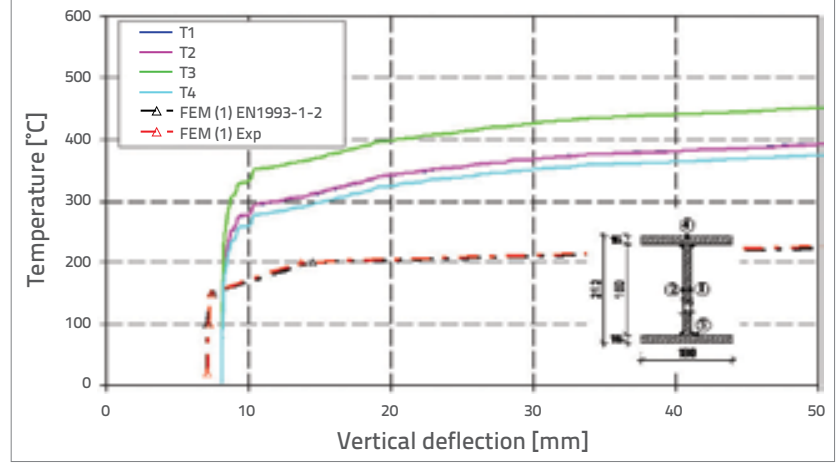

Figure 13. Deflection at midspan for the element subjected to bending (transient test, V=275 kN)

The difference between the deflections obtained by experiments and simple calculation models is greater when the element is exposed to combined bending and longitudinal compression due to the influence of the second order theory in the computation of inner forces which, in combination with the assumption of the ideal elasto-plastic behaviour of steel at high temperatures, gives rather an unrealistic prediction of the element deflections. It should be pointed out that the used FEM models, 1 and 2, predict midspan deflections when the stresses in the crosssection are lower than the values of the reduced yield strength of steel $f_{y, \Theta}$ at a given temperature. This suggests that the element deflections were calculated only up to the beginning point of the plastic behaviour of steel. Furthermore, high deviations between the results of the experiment and model predictions are present because of the assumed uniformity of the modulus of elasticity for the part of the element in the furnace due to inability of the software to have a discretization over the cross-section. As a consequence, numerical analysis is conducted with a lower element stiffness than the realistic one, therefore, greater deflections and lower collapse forces of the element are obtained by the numerical analysis (Figures 10 and 11). It is also evident that, by varying the parameters of the yield strength and the elastic modulus given by HRN EN1993-1-2:2008, and the values of the same parameters obtained by experiments, very similar predictions of element deflections are obtained. In addition, greater deviations between the experimental and numerical deflections exist due to inability of the numerical model [17] to include steel creep strains into analysis. Figures 12 and 13 show a good prediction of midspan deflection by using SCIA model 1 in comparison to the experimentally determined deflections for lower stress level in the element: predictions of the critical temperature according to the SCIA model 1 are ca 10\% lower than the actual critical temperature, while for higher stress levels in the element, prediction of the critical temperature of the model is ca $35 \%$ lower than the actual critical temperature.

\subsection{Calculation of the ultimate load resistance of elements according to HRN EN1993-1-2:2008}

The calculation of the ultimate load bearing resistance moment of the analyzed elements for class 1 and 2 cross- section, subjected to bending in accordance with HRN EN1993-1-2:2008, is determined by two expressions:

$M_{t i, \Theta, R d}=k_{y, \Theta} \cdot W_{p l, y} \cdot f_{y}$

$M_{f i,, R d}=\frac{k_{y, \Theta} \cdot W_{p l, y} \cdot f_{y}}{\kappa_{1} \cdot \kappa_{2}}$

where:

$k_{y, \Theta} \quad$ - reduction coefficient for the yield strength of steel,

$W_{p l, y}$ - plastic section modulus,

$f_{y} \quad$ - yield strength of steel,

$\kappa_{1}, \kappa_{2}$-factors which take into account the non-uniform temperature distribution over the element's crosssection and over the length of the element.

Expressions (1) and (2) were given for elements for which the lateral torsional buckling was prevented. The expressions are adequate for the performed experimental procedure in which the element in the furnace was laterally supported at midspan. Since there was a temperature difference between the upper and lower flange of the analyzed elements ranging from $30-50^{\circ} \mathrm{C}[16]$, and since only one half of the element was heated to high temperatures, the adaptation factors $\kappa_{1}$ $=0.7 \mathrm{i} \kappa_{2}=1.0$ were chosen for the calculation of the ultimate resistance moment during fire action, according to HRN EN1993-1-2:2008 recommendations.

The interaction formula for the assessment of the load bearing capacity of the elements exposed to a longitudinal compression and bending is given by expression:

$\frac{N_{f, E d}}{\chi_{\min , f i} \cdot A \cdot k_{y, \theta} \cdot f_{y}}+\frac{k_{y} \cdot M_{y, f i, E d}}{W_{p l, y} \cdot k_{y, \theta} \cdot f_{y}} \leq 1.0$

gdje je:

$N_{\text {fi,Ed }}$ - external compressive force

$M_{y, f i, E d}$ - moment of the external vertical force

$k_{y} \quad$ - coefficient that takes into account the non-uniform distribution of the bending moment over the element

$\chi_{\text {min,fi }}$ - reduction coefficient in case of fire for the crosssection axis with the highest slenderness

A - surface area of the cross-section.

The resistance moment of the cross-section $M_{f i \Theta, R d}$ obtained according to expressions (1) and (2) makes it possible to determine the collapse force from the equality of the moment of external forces $M_{y, f i, E d}$ and the resistance moment $M_{f i \Theta, R d^{*}}$ The same applies to the interaction expression (3) where the moment of external vertical forces $M_{y, f i, E d}$ is sought at with the left side of the interaction expression (3) equalling one. Figure 14 presents the vertical collapse force at which the load bearing capacity of an element is exceeded when the moment of external forces $M_{y, f i, E d}$ is equal to the resistance moment $M_{f i \Theta, R d}$ obtained by expressions (1) and (2) depending on the temperature at which an element was heated. The figure also presents a comparison between the obtained collapse 


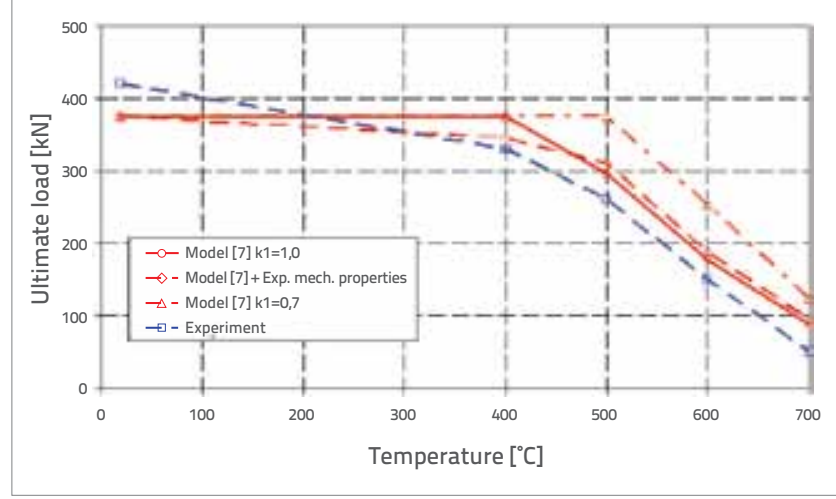

Figure 14. Collapse vertical force depending on temperature - the comparison of experimental results with the predictions made by HRN EN1993-1-2:2008 for bending

forces for the case of two different values of the adaptation factor $\kappa_{1}$ and the collapse force of the element obtained by the experiment for the case of the steady-state heating. It is evident that the expressions taken from HRN EN1993-12:2008 predict values of collapse forces ca $15 \%$ greater than those obtained by the experiment when using expression (1), while higher deviations amounting to ca $40 \%$ occur when using expression (2).

Figure 15 presents the collapse force, at which the element's load bearing capacity is exceeded, calculated by using expression (3), depending on temperature for the element exposed to the combined bending and longitudinal compression. The results show that for the case of combined bending and longitudinal compression the predictions of the collapse force according to HRN EN1993-1-2:2008 are on the safe side ranging from $10-30 \%$.

\section{Conclusion}

Considering the performed experimental and theoretical study the following conclusions can be reached:

- For the analysed batch of steel samples, grade S355, the mechanical properties including the stress-strain curves at high temperatures can be approximated with sufficient precision using the values given in HRN EN1993-1-2:2008,

- The deflections of the elements which are tested by the steady-state heating method and subsequently loaded cannot be calculated with sufficient precision using the available engineering structure modelling software [17]

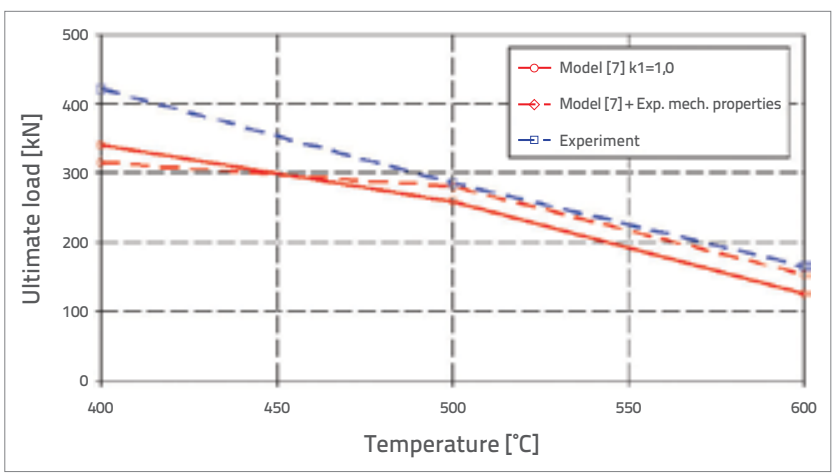

Figure 15. Collapse vertical force depending on temperature the comparison of the experimental results with the predictions of Eurocode 3 for combined bending and longitudinal compression

due to inability of the software to take into account the material nonlinearity including the influence of the creep strains on different levels of stress and temperature,

- More precise predictions of the deflections using the engineering structure modelling software [17] were identified in the case of transient heating method where, because of the type of the testing method, the deviations of the results for lower stress levels are almost negligible, while at higher stress levels the deviations occur exclusively because the effect of steel creep at high temperatures was not taken into account,

- The collapse forces, which are calculated via the load bearing resistance moment of the steel element exposed to fire in the case of non-uniform temperature distribution over the cross-section, and via the adaptation factors $\kappa_{1}$ and $\kappa_{2^{\prime}}$ produce results which are not on the safe side with regard to the values obtained by this study; hence, it is necessary to reduce their use in engineering calculations of the load bearing capacity of steel elements at high temperatures.

\section{Acknowledgement}

The research described in this paper was carried out within the scientific projects No. 083-1465 "Reliability of structures and risk assessment to extreme loading" and No. 083-00000001538 "Experimental and numerical research of earthquake resistance of structures" supported by the Ministry of Science, Education and Sport of the Republic of Croatia. 


\section{REFERENCES}

[1] Phan, L. T., McAllister, T. P. \& Gross, J. L.: Best Practice Guidelines for Structural Fire Resistance Design of Concrete and Steel Buildings, NISTIR 7563, Draft version, Building and Fire Research Laboratory, NIST, 2009.

[2] Dwaikat, M. \& Kodur, V.: Performance Based Design Approach for Evaluating Fire Resistance of Restrained Steel Beams, Proceedings of the Sixth International Conference Structures in fire, Michigan, pp. 106-113, 2010.

[3] Takagi, J. \& Deierlein, G. G.: Strength Design Criteria for Steel Members at Elevated Temperatures, Journal of Constructional Steel Research, 63, (2007), 8, pp. 1036-1050.

[4] Vila Real, P.M.M., Piloto, P.A.G. \& Franssen, J.-M.: A new proposal of a simple model for the lateral-torsional buckling of unrestrained steel I beams in case of fire: experimental and numerical validation, Journal of Constructional Steel Research 59, (2003), 2, 179-199.

[5] Bailey, C. G., Burgess, I. W. \& Plank, R. J.: The Lateral-torsional Buckling of Unrestrained Steel Beams in Fire, Journal of Constructional Steel Research 36, (1996), 2, 101-119.

[6] Franssen, J. M., Kodur, V. \& Zaharia, R.: Designing Steel Structures for Fire Safety, CRC Press, London, UK, 2009.

[7] HRN EN 1993-1-2:2008, Eurocode 3 - Design of steel structures - Part 1-2: General Rules Structural Fire Design, European Committee for Standardization, Brussels, 2005.

[8] Boko, I.: Određivanje stupnja sigurnosti nosivih čeličnih konstrukcija izloženih djelovanju požara, doktorska disertacija, Građevinsko-arhitektonski fakultet Split, 2005.
[9] Schleich, J.B.: Maximum stress level of structural steel in function of the temperature - strain hardening included through numerical simulations of uniformly heated steel beams during transient state bending tests, Working documents, Luxembourg, 1988-1989.

[10] Wainman, D. E. \& Kirby, B. R.: Compendium of UK Standard Fire Test Data: Unprotected Structural Steel -1 \& 2, British Steel Corporation, 1988

[11] Cooke, G. M. E.: An introduction to the Mechanical Properties of Structural Steel at Elevated Temperatures, Fire Safety Journal, 13, (1988), pp. 45-54.

[12] Kirby, B.: The Behaviour of Structural Steels Manufactured by BSC under Stress Controlled Anisothermal Creep Conditions, Report SH/RS/3664/4/83/B, BSC Sheffield Laboratories, 1983.

[13] Kirby, B. R. \& Preston, R. R.: High Temperature Properties of Hot-Rolled, Structural Steels for Use in Fire Engineering Design Studies, Fire Safety Journal, 13, (1988), pp. 27-37.

[14] Boko, I., Peroš, B. \& Torić, N.: Pouzdanost čeličnih konstrukcija u požaru, Građevinar, 62, (2010), 5, pp. 389-400.

[15] Kruppa J., Twilt L., Weche J. \& Cooke J.: Fire Protection of Structural Steelwork, ECSC project SA 314, 1995.

[16] Boko, I., Torić, N. \& Peroš, B.: Analiza proračunskih modela provođenja topline iz EN1993-1-2, Građevinar 64, (2012), 4, pp. 285-292.

[17] SCIA Engineer 2008 Manual, Advanced calculations, Nemetschek Scia, 2008. 